\title{
A Conceptualization of the Effect of Organisational Justice on Turnover Intention: The Mediating Role of Organisational Citizenship Behaviour
}

\author{
Oussama Saoula $^{1}$, Muhammad Fareed ${ }^{1}$, Saiful Azizi Ismail ${ }^{1}$, Nurul Sharniza Husin ${ }^{1} \&$ Rawiyah Abd Hamid ${ }^{1}$ \\ ${ }^{1}$ School of Business Management, College of Business, Universiti Utara Malaysia, Kedah, Malaysia \\ Correspondence: Rawiyah Abd Hamid, School of Business Management, College of Business, Universiti Utara \\ Malaysia, 06010 Sintok, Kedah, Malaysia.
}

Received: April 30, 2019

Accepted: May 30, 2019

Online Published: June 11, 2019

doi:10.5430/ijfr.v10n5p327

URL: https://doi.org/10.5430/ijfr.v10n5p327

\begin{abstract}
Considering employees are the ultimate valuable assets, most companies nowadays give lots of effort and capitalise vital resources to preserve them. The turnover of those employees will affect the achievement of the organisations' goals as well as the maintaining of the competitive advantage. Therefore, it is imperative to call for more studies to understand the factors affecting this phenomenon in different settings and contexts of research, particularly in the non-western perspectives such as Malaysia who is facing big challenges toward the employees' turnover in many sectors. Therefore, the drive of this paper is to examine the relationship between organisational justice (OJ), organisational citizenship behaviour (OCB) (benefiting the individual OCB-I and benefiting the organisation OCB-O) and turnover intention (TI). Consequently, this study proposed framework to study the effect of organisational justice on turnover intention via the mediation role of organisational citizenship behaviour (OCB-I, OCB-O). Also, the direct impact between the variables has been discussed. Hence this paper is expected to fill the research gap and contribute to the body of knowledge in this area of research.
\end{abstract}

Keywords: turnover intention, organisational justice, organisational citizenship behaviour, social exchange theory

\section{Introduction}

The problem of employees' turnover converted to be a main obstacle to the companies due to its effect on the long-term plan and the productivity of these organisations (Keni, 2013). Essential postulation is that employees in the form of human capital, are accountable for the firms' results since they are the ones who advance and implement firm's strategies and processes and eventually determine its success level (Fareed, Noor, Isa, \& Salleh, 2016; Deacon \& Van Rensburg 2018). Therefore, retaining capable employees is one of the most key indicators of achieving competitive advantage (Sayin et al., 2019), particularly when companies are active in a competitive environment which created the necessity to manage and preserve their workforce (Chib, 2016; Hamid, Reihaneh, \& Siroos, 2016; Kim \& Hyun, 2017; Lin, Tsai, \& Mahatma, 2017; Parasız, Koç, Ilgar, \& Şahin, 2017). Moreover, employees' turnover considered as costly phenomena to the organisations, and this cost will appear in several faces such as termination, advertisements, recruitment, selection and training (Abid \& Butt, 2017; Labrague, Gloe, McEnroe-Petitte, Tsaras, \& Colet, 2018; Long, 2016; Parasiz et al., 2017; Sumaira Khalid, Ch. Abdul Rehman, \& Muqadas, 2018). To get better solutions to the problems related to high turnover rates, examining the fundamental reasons is very important to be considered by the organisations, which they have to ask a vital question, why some employees leave, and some remain? The motives may appear difficult and interconnected to the favourites and needs of the individuals. This study focuses on turnover intention instead of turnover (the actual behaviour) because the intention is the robust predictor of turnover (prevention is better than cure) (Lin et al., 2017; Brown \& Ibekwe 2018). One of the valid indicators of positive outcomes and performances is the employee producing extra role behaviour which is not included in the compensation system, which is called organisational citizenship behaviour (Deery, Rayton, Walsh, \& Kinnie, 2017; Rurkkhum \& Bartlett, 2017; Demirel,et.al 2018). Companies should ensure producing and maintaining a good level of this kind of behaviours (Deery et al., 2017; Patiraj \& Shivani, 2017; Rurkkhum \& Bartlett, 2017), as it has a significant effect on different organisational outcomes such as employees' turnover (Saoula, Johari, \& Fareed, 2018). The reasons behind having a low level of OCB and high intention of turnover among employees are assumed to be due to many factors. Therefore, investigating these factors such as organisational justice which influences OCB and turnover intention is essential. Saoula, Johari, and Bhatti (2016) in 
their proposed research on the mediating effect of OCB on the relationship between personality traits and turnover intention recommended that future researchers should engage factors such as organisational justice in similar models and contexts of research.

From the findings of the previous studies, the majority of studies on the relationship between organisational justice and turnover intention have focused more on the two dimensions of the organisational justice (i.e., distributive justice and procedural justice) while little studies explored the effect of interactional justice. Hence, the current research will focus on the three dimensions of organisational justice (distributive, procedural and interactional) and their impact on OCB and employee turnover intention. Also, among the different known organisational citizenship behaviour models, this study will use Williams and Anderson (1991) conceptualisation of OCB that consists of two dimensions (OCB to benefit the individuals OCB-I and OCB to benefit the organisation OCB-O).

The majority of the past studies on the effect of OJ on OCB and turnover intention have been conducted in the western contexts (developed countries) which have differences in national cultures compares to non-western contexts (developing countries) which make the finding not generalised and applicable to the different settings of research. Therefore, more investigations on the relationship between OJ, OCB and turnover intention will contribute to the body of knowledge and support the literature review in this filed and fill the research gap in Malaysia mainly and Asia and the world in general. According to study entitled "APAC Year on Year Attrition Rate (2009-2011)" conducted by a human capital consulting and outsourcing firm (AON Hewitt), in the Asia Pacific region, Malaysia was placed sixth in 2011 for employees' turnover with attrition rate of 15.9\% (Langove, Isha, \& Javaid, 2016). Moreover, according to the Malaysia Employers Federation (MEF), Information and Communication Technology (ICT) sector in Malaysia is the most confronting with the challenge of a turnover issue with a turnover rate of more than 75\% (Nasyira, Othman, \& Ghazali, 2014; Diemer,et.al 2018), which is genuinely the most affected than other sectors. Therefore, there is need to call for more investigations to understand the reasons behind it in this context.

\section{Review of the Literature}

\subsection{Turnover Intention (TI)}

Tett and Meyer (1993) defined turnover intention as "a conscious willingness to leave the organisation, which includes a thought or idea of leaving, the behaviour of searching for a new job, and the behaviour of deciding to leave the job" (p.262). Ongori (2007) argued that any plan by the employee to leave the organisation mean turnover intention which considered being the direct precursor to the actual behaviour of quitting. Due to its damaging effects on the organisation, the phenomena of employee' turnover, became the main interest of professionals, academicians, practitioners and organisations' managers who have spent enough attention for it (Abid \& Butt, 2017; Muqadas, Rehman, \& Aslam, 2017; Sumaira Khalid et al., 2018; Ton \& Huckman, 2008)

\subsection{Organisational Justice}

The term "organisational justice" was used to define a set of social psychological and sociological theories that defined perceptions of fairness by illustrating how organisational justice could be applied to organisations effectively (Greenberg, 1987). In today's terms, organisational justice is associated with numerous distinct forms of what is commonly referred as perceived justice, with each form of perceived justice offering several responses to the question, "What is fair?" (Greenberg, 2009). The three dimensions of organisational justice and their definitions are as the following:

\subsubsection{Distributive Justice (DJ)}

In the early conceptualisations of organisational justice, theorists focused on distributive justice, which is defined by Greenberg (1990) as "an individual`s judgment or perceived fairness of resource allocation, based upon the produced outcomes of the individual compared to expected inputs".

\subsubsection{Procedural Justice (PJ)}

The theory of procedural justice was developed by Thibaut and Walker (1975) study of responses to the argument determination process in the legal system. Thibaut and Walker explored how disputants` perceived control over the process and how the decisions would impact their perception of final verdicts.

\subsubsection{Interactional Justice (IJ)}

Besides distributive and procedural justice, researchers have also found that the quality of interpersonal treatment that individual receives will affect the perception of justice. The construct was termed by Bies and Moag (1986) as interactional justice. 


\subsection{Organisational Justice and Turnover Intention}

Social exchange theory of Blau (1964) asserts that the continuous contribution is a way used by the individuals to pay back the favourable treatments from their organisation. So, the association between organisational justice and employee' turnover intention is developed based on the construct provided by this theory (Karatepe \& Shahriari, 2014). Many recent studies have proven the negative effect of organisational justice (distributive, procedural and interactional) on employees' turnover intention in may contexts (Fatt, Khin, \& Heng, 2010; Karatepe \& Shahriari, 2014; Ponnu \& Chuah, 2010; Sayed, Mohammad, Hossein, Yashar, \& Hamid, 2012). Contrariwise, there is a study in Malaysia proved that organisational justice does not have any association with the turnover intention (Saraih, Aris, Sakdan, \& Ahmad, 2017). This finding inconsistent with the results of many previous studies, which means that there are mix results in the relationship between organisational justice and turnover inaction. Hence, to fill the literature and practical gaps, further empirical studies on the direct and indirect effect of organisational justice on turnover intention are needed particularly in the Malaysia context. Based on the earlier discussion, the following proposition was formulated:

P1: Organisational justice (distributive, procedural and interactional justice) has a significant negative effect on employees' turnover intention.

\subsection{Organisational Justice and Organisational Citizenship Behaviour}

Social exchange theory provided strong guidelines for explaining the association between organisational justice and organisational citizenship behaviour; it indicates that the social connections at workplace impact the employees' behaviours and attitudes (Dalal, 2005). If the employees are treated positively, they will feel obligated to pay back in the same manner (Walumbwa, Hartnell, \& Oke, 2010). Contrariwise, if the employees receive unfair treatment, reacting negatively towards these actions will be very high. Generally organisational justice indicates the level of respect and appreciation towards employees (Walumbwa et al., 2010). The more the organisational justice is promoted, the more levels of OCBs will be exhibited. Therefore, organisational justice has been considered as an effective attitudinal precursor of OCB (Lv, Shen, Cao, Su, \& Chen, 2012). Research finding from previous studies have proven the positive effect of OJ (i.e., distributive, procedural and interactional) on OCB (Ince \& Gül, 2011; Mohammad, Habib, Adnan, \& Alias, 2010; Noruzy, Shatery, Rezazadeh, \& Hatami-Shirkouhi, 2011; Sayed et al., 2012; Shahzad \& Jamal, 2013) .Contrariwise, there is a study in Malaysia by Khan and Rashid (2012), revealed that $\mathrm{OJ}$ is not significant in explaining OCB. This finding is inconsistent with the results of many previous studies, which means that there are mix results in the relationship between OJ and OCB. Hence, in order to fill the literature and practical gaps, further empirical studies on the effect of OJ on OCB are needed particularly in the Malaysian context. Based on the earlier discussion, the following proposition was formulated:

P2. Organisational justice (distributive, procedural and interactional justice) has a significant positive effect on organisational citizenship Behaviour (benefiting the individual OCB-I and benefiting the organisation OCB-O)

\subsection{Organisational Citizenship Behaviour and Turnover Intention}

According to Harrison, Newman, and Roth (2006), OCBs can be observed as one of the primary stages of the withdrawal process. This process encompasses a variety of behaviours, each reflecting a practice of intentional reaction by an employee to deal with a disagreeable work environment. Therefore OCB is considered as one of the behaviours that are related to the quitting process (Berry, Lelchook, \& Clark, 2012). Recent empirical studies have shown the effectiveness of OCB in predicting Employees' turnover intention and proven the negative association between OCB and turnover intention (Barzoki \& Rezaei, 2017; Berry et al., 2012; Coyne \& Ong, 2007; Iftikhar, Shahid, Shahab, Mobeen, \& Qureshi, 2016; Li, Kim, \& Zhao, 2017; Mazlum Çelik, 2013; Paillé \& Grima, 2011; Podsakoff, Whiting, Podsakoff, \& Blume, 2009; Rekik, 2018; Chima \& Kasim, 2018; Ngigi \& Odiyo, 2017; Orora., Keraro, \& Wachanga, 2014). Hussien, F. M., \& Jones, E. (2016). Kabir, K. H., \& Aftab, S. (2017).). Contrariwise, some studies showed different results on the relationship between OCB and turnover intention (Koys, 2001; Lau, McLean, Lien, \& Hsu, 2016; Paillé, 2013; Saraih et al., 2017; Romli and Ismail, 2014; Ekpung, 2014; Sarwar and Mubarik, 2014 ; Okon and Monday, 2017; Kimengsi and Gwan, 2017; Bollazzi and Risalvato, 2018). For instance, Koys (2001) did not find proofs proposing that OCB is a predictor of employee turnover. In addition, Paillé (2013) found that OCB is positively related to turnover intention, which was the unexpected result, and he suggested that more investigations are required to extend the understanding of the association between OCB and turnover intention. Similarly, Lau et al. (2016), indicated that self-rated OCB increased turnover intention positively, which means self-rated OCB did not influence turnover intention. Furthermore, Saraih et al. (2017), found that OCB does not have any association with turnover intention.

According to the findings of the previous studies on the effect of OCB on employees` turnover intention, mix results 
have been reported on the relationship between the two variables. Thus there is a need for more investigations on the effect of OCB on TI, particularly in the Malaysian Context. As per the best knowledge of the researcher, in the Malaysian context particularly in the service sector, there are limited studies have examined the association between OCB and turnover intention. Based on the above discussion, this study assumed that OCB' two dimensions (i.e., OCB-I, OCB-O) have a significant negative effect on employees' turnover intention. Accordingly, the following proposition was formulated:

P3. Organisational citizenship behaviour (benefiting the individual OCB-I and benefiting the organisation OCB-O) has a negative effect on employees' turnover intention.

\subsection{Organisational Citizenship Behaviour as a Mediator}

OCB is a term includes any constructive and positive action done by the employees, based on their own willing, which help colleagues and support the organisation, support co-workers and benefits the company (Chib, 2016). For great deal of time, organisational citizenship behaviours (OCB) have taken the attention of both practitioners and academicians, because it is recognized as one of the serious issues that should be investigated in the area of organisational behaviour (Martinez \& Podsakoff, 2016; Patiraj \& Shivani, 2017; Podsakoff et al., 2009; Rurkkhum \& Bartlett, 2017). Therefore, The organisations should be aware of the importance of OCB through engaging it in the performance appraisal to support it among employees and pay attention to this behaviour due to its importance in improving the effectiveness of the organisational operations and have a vital role in decreasing the level of employee turnover (Khan \& Rashid, 2012; Patiraj \& Shivani, 2017). Hence, it is a significant issue of investigation for both researchers and practitioners to understand the working mechanism of OCB in the organisations (Patiraj \& Shivani, 2017; Purba, Oostrom, Van Der Molen, \& Born, 2015; Rurkkhum \& Bartlett, 2017; Wang \& Bowling, 2016). As per the best knowledge of the researcher, in the literature of turnover intention in the ICT sector in Malaysia, OCB was not used before to mediate the relationship between OJ and turnover intention. Yadav and Punia (2013) argued that, although investigating OCB has improved the body of knowledge in this field, OCB still a new area of research displaying issues related to new theory development (Ahmed, Majid \& Zin, 2016; Ali \& Haseeb, 2019; Haseeb, Abidin, Hye, \& Hartani, 2018; Haseeb., 2019; Suryanto, Haseeb, \& Hartani, 2018). Also, Islam, Ahmed, and Ahmad Ungku (2015) recommended OCB to be considered as a mediator in the future studies on turnover intention researches. Furthermore, Saoula and Johari (2016) in their proposed research framework on the mediating effect of $\mathrm{OCB}$ on the relationship between perceived organisational support and turnover intention recommended that future researchers should engage factors such as organisational justice in similar models and contexts of research. Moreover, the existing literature on the relationship between OJ and turnover intention showed mix results Saraih et al. (2017). Therefore, adding OCB as a mediator variable in the model of this study will fill the literature gap as proposed by the researchers in the literature. On this score, the present study argues that OCB to have a theoretical mediating effect in predicting and reducing turnover intention organisational justice is taken into account. This study assumed OCB's two dimensions (i.e., OCB-I, OCB-O) play a role in mediating the effect of OJ's three dimensions (i.e., distributive justice, procedural justice and interactional justice) on turnover intention. Based on this assumption, the following proposition was formulated:

P4. Organisational citizenship behaviour (benefiting the individual OCB-I and benefiting the organisation OCB-O) mediates the effect of organisational justice (distributive, procedural and interactional justice) on turnover intention.

\section{Proposed Conceptual Framework}

Initial research framework (Figure 1) has been developed base on the extensive and comprehensive review of the literature and support of the theory. Social exchange theory has been used to support and consolidate the effect between organisational justice, organisational citizenship behaviour and turnover intention. Social exchange theory suggests that through the mutual exchange, a pattern of reciprocal obligation is established between the parties (Blau, 1964). The benefited party becomes obligated to pay back throughout positive outcomes (e.g., high OCB and low intention to leave). When the exchanges are regarded as fair over time, the perception of organisational justice will prevail among organisational members and the coherence of the organisation will be enhanced. Furthermore, this theory provides findings which indicate that employees exchange desirable outcomes in return for fair treatment, support or care (Paillé, 2013).

This research contributes to the body of knowledge via developing a conceptual framework (Figure 1) that hypothesized the direct effect of OJ (DJ, PJ and IJ) on OCB's two dimensions (OCB-I, OCB-O) and on turnover intention as well as the effect of OCB's two dimensions (OCB-I, OCB-O) on turnover intention. Furthermore, this research proposed the investigation of the mediations effect of OCB's two dimensions (OCB-I, OCB-O) on the relationship between $\mathrm{OJ}$ (DJ, PJ and IJ) and turnover intention to bring more insights into these effects mainly in the 
Malaysian context.

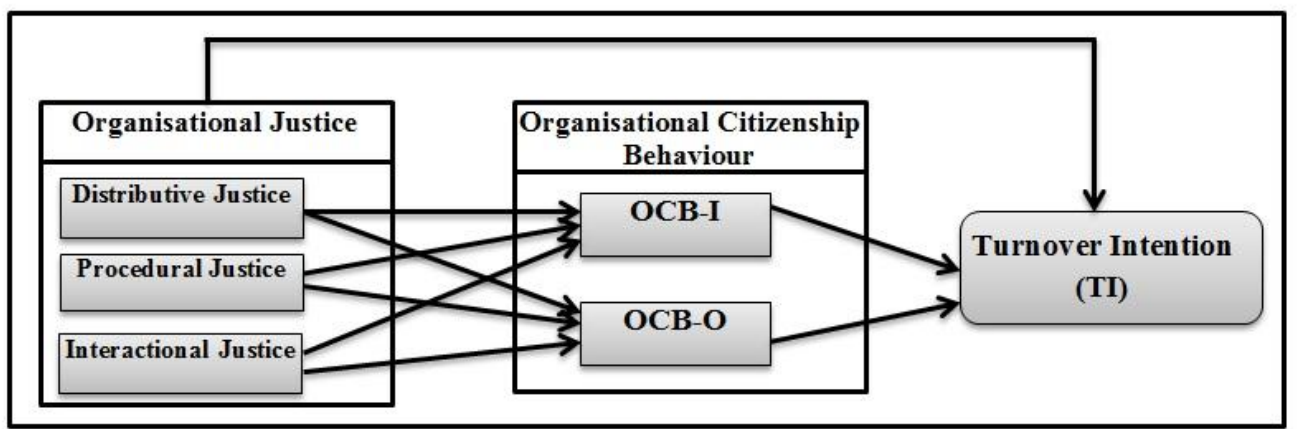

Figure 1. Proposed conceptual framework

\section{Methodology}

This paper highlights a proposed framework on essential factors affecting turnover intention. Quantitative approach has been proposed by the researcher to test the phenomenon. The population of this study is the full-time employees working in the Information and Communication Technology (ICT) service sector in Klang Valley area (Malaysia), as this area contains the highest number of employees working in this sector (96\%). Therefore the population of this study is 128,859 employees working in the ICT service sector in the Klang Valley area in Malaysia (Department of Statistic, 2014). Based on the sampling table suggested by Krejcie and Morgan (1970), the number of samples required to represent this population ( 128,859 employees) is 382 . The survey questionnaire will be distributed among the targeted employees to collect important data. The measurement will be adapted from existing literature. To test the proposed model, the Structural Equation Modeling -Partial Least Square (SEM-PLS) will be employed to establish the validity and reliability of the measurements and to test the postulated hypothesis. The soft modelling assumptions of PLS technique (i.e. ability to flexibly develop and validate complex models) gives it the advantage of estimating large complex models (Akter, D'Ambra, \& Ray, 2011). Furthermore, A detailed assessment of the management literature exposes that PLS-SEM is widely being accepted as a non-parametric technique of testing model in last decade (Auf, Meddour, Saoula, \& Majid, 2018; Fareed, Isa, \& Noor, 2016). In addition, structural equations models have been demonstrated to be superior models to perform estimations better than regressions for assessing mediation (Iacobucci, Saldanha, \& Deng, 2007; Preacher \& Hayes, 2004). PLS path modelling is proposed for this study to help avoid any normality problem that might arise in the course of data analysis for the current research. In most social science studies, data tend to have normality problem (Osborne, 2010), and PLS path modelling does not necessarily require data to be normal (Shackman, 2013; Azida, et.al 2018). In other words, PLS treats non-normal data relatively well. In addition, Tabachnick and Fidel (2007) indicated that SEM-PLS is one of the most powerful statistical tools in social and behavioural sciences that can test several relationships simultaneously.

\section{Conclusion}

As aforementioned, this study is to investigate the effect of OJ on turnover intention, and the mediating role played by OCB in the relation. By providing empirical evidence on these perceptions, this research is expected to support managers, practitioners and decision makers in their organisations to identify the real sources of turnover intention. The past researchers have tried to link OJ with turnover intention, but they have ignored the role of OCB as a vital predictor of turnover intention in this relation. As the organisations aim to prevent the turnover from happening, the better way of doing that is increasing the level of citizenship behaviour among employees. Thus, the use of OCB in the relationship between OJ and turnover intention will help in the early prediction of turnover intention and provide a better understanding of the relations between the variables and fill the research gap raised by previous researchers.

\section{Recommendations for Future Research}

The current study acknowledged having some limitations. This research proposed a conceptual framework to investigate the effect of only one variable (OJ) on TI directly and indirectly through the mediation role of only one variable (OCB). Moreover, this study proposed to be examined in ICT service sector in Malaysia. In addition, this 
research suggested using only one theory (SET) to be tested. Therefore, some recommendations for future research will be worthy. It is strongly recommended that future studies should examine this research model empirically. Furthermore, future researchers are encouraged to consider adding other factors affecting turnover intention (e.g., Career anchors and career development opportunities). Also, future studies should consider different dependent variables in similar research (e.g., job embeddedness) as it is an important concept in the retention strategies of companies. Moreover, future researchers should also consider any possible role of other mediators (e.g., perceived organisational support) and the potential role of moderators (e.g., personality traits, organisational learning culture) to provide new insights to contribute to the body of knowledge in the turnover intention literature. In addition, future studies should propose this conceptual framework to be investigated in different sectors and using other theories rather than SET.

\section{References}

Abedin, M. T., \& Dawan, M. M. (2016). A Panel Data Analysis for Evaluating the Profitability of the Banking Sector in Bangladesh. Asian Journal of Economics and Empirical Research, 3(2), 163-171. https://doi.org/10.20448/journal.501/2016.3.2/501.2.163.171

Abid, G., \& Butt, T. H. (2017). Expressed Turnover Intention: Alternate Method for Knowing Turnover Intention and Eradicating Common Method Bias. International Letters of Social and Humanistic Sciences, 78, 18-26. https://doi.org/10.18052/www.scipress.com/ILSHS.78.18

Adusei, C. (2018). Public Procurement in the Health Services: Application, Compliance and Challenges. Humanities and Social Sciences Letters, 6(2), 41-50. https://doi.org/10.18488/journal.73.2018.62.41.50

Agbim, K. C., \& Eluka, J. (2018). Social Network and Family Business Internationalization in South Eastern Nigeria. Journal of Accounting, Business and Finance Research, 3(2), 64-74. https://doi.org/10.20448/2002.32.64.74

Ahmed, U., Majid, A. H. A., \& Zin, M. L. M. (2016). HR Moderating HR: Critical link between Developmental HR Practices and work engagement in a Moderated Model. Management Review: An International Journal, 11(2), 4.

Akter, S., D'Ambra, J., \& Ray, P. (2011). An evaluation of PLS based complex models: the roles of power analysis, predictive relevance and GoF index.

Ali, A., \& Haseeb, M. (2019). Radio frequency identification (RFID) technology as a strategic tool towards higher performance of supply chain operations in textile and apparel industry of Malaysia. Uncertain Supply Chain Management, 7(2), 215-226. https://doi.org/10.5267/j.uscm.2018.10.004

Amfani-Joe, C. E., Okonkwo, L., \& Osagede, E. A. (2018). Socio-demographic Structures of Families as Predictors of Time Management by Working Housewives in the Federal Capital Territory (FCT), Abuja, Nigeria. International Journal of Social Sciences Perspectives, 3(1), 1-6. https://doi.org/10.33094/7.2017.2018.31.1.6

Angbre, F. A. (2016). The Role of Agricultural Education in Ensuring National Security in Nigeria. Agriculture and Food Sciences Research, 3(1), 25-28.

Auf, M. A. A., Meddour, H., Saoula, O., \& Majid, A. H. A. (2018). Consumer buying behavior: the roles of price, motivation, perceived culture importance, and religious. Journal of Business and Retail Management Research, 12(4), 186-195. https://doi.org/10.24052/JBRMR/V12IS04/ART-18

Azida, A. B., Farina, M. H., Zuhaida, M. Z., Fauzi, B., \& Hasbullah, H. B. (2018). Implementation of Open-Ended Laboratory (OEL) in Environmental Engineering Subject for Civil Engineering Diploma Program. International Journal of Asian Social Science, 8(4), 173-178. https://doi.org/10.18488/journal.1.2018.84.173.178

Barzoki, A. S., \& Rezaei, A. (2017). Relationship between perceived organisational support, organisational citizenship behaviour, organisational trust and turnover intentions: an empirical case study. International Journal of Productivity and Quality Management, 21(3), 273-299. https://doi.org/10.1504/IJPQM.2017.084456

Berry, C. M., Lelchook, A. M., \& Clark, M. A. (2012). A meta-analysis of the interrelationships between employee lateness, absenteeism, and turnover: Implications for models of withdrawal behavior. Journal of Organizational Behavior, 33(5), 678-699. https://doi.org/10.1002/job.778

Bies, R. J., \& Moag, J. S. (1986). Interactional justice: Communication criteria of fairness. Research on Negotiation in Organizations, $1(1), 43-55$.

Blau, P. M. (1964). Exchange and power in social life. Transaction Publishers. 
Brown, E. D., \& Ibekwe, E. E. (2018). Effect of Institutional Factors on Foreign Direct Investment in Nigeria. The Economics and Finance Letters, 5(1), 12-27. https://doi.org/10.18488/journal.29.2018.51.12.27

Chang'ach, J. K. (2018). An Historical Trajectory of the Economic Transformation of the Southern Keiyo Community in Kenya. Global Journal of Social Sciences Studies, 4(2), 52-69. https://doi.org/10.20448/807.4.2.52.69

Chib, S. (2016). Study on organizational commitment and workplace empowerment as predictors of organization citizenship behaviour. Scholedge International Journal of Management \& Development, 3(3), 63-73. https://doi.org/10.19085/journal.sijmd030301

Chidobi, R. U. (2017). Extent of Implementation of Nuc Regulation by Private Universities in Enugu State on Personnel Management. American Journal of Education and Learning, 2(1), 83-91. https://doi.org/10.20448/804.2.1.83.91

Chiekezie, N. R., Egbunike, P. A., \& Odum, A. N. (2014). Adoption of competitor focused accounting methods in selected manufacturing companies in Nigeria. Asian Journal of Economic Modelling, 2(3), 128-140.

Chima, P., \& Kasim, U. (2018). Public-Private Partnership as a Strategy for E-Governance Funding in Africa: The Gains and the Pains. International Journal of Public Policy and Administration Research, 5(2), 37-47. https://doi.org/10.18488/journal.74.2018.52.37.47

Coyne, I., \& Ong, T. (2007). Organizational citizenship behaviour and turnover intention: a cross-cultural study. The International Journal of Human Resource Management, 18(6), 1085-1097. https://doi.org/10.1080/09585190701321831

Dalal, R. S. (2005). A meta-analysis of the relationship between organizational citizenship behavior and counterproductive work behavior. Journal of Applied Psychology, 90(6), 1241-1255. https://doi.org/10.1037/0021-9010.90.6.1241

Deacon, E., \& Van Rensburg, E. (2018). Emotional and Social Competence in School Beginners: An Intervention Programme for Teachers and Therapists. American Journal of Education and Learning, 3(2), 85-92. https://doi.org/10.20448/804.3.2.85.92

Deery, S., Rayton, B., Walsh, J., \& Kinnie, N. (2017). The costs of exhibiting organizational citizenship behavior. Human Resource Management, 56(6), 1039-1049. https://doi.org/10.1002/hrm.21815

Demirel, I. N., Teyfur, M., Çelik, I., Safali, S., \& Kaya, A. (2018). Perspectives of Preservice Teachers on the Statements Related to Preservice Teachers and Competence of Lecturers. Journal of Education and e-Learning Research, 5(3), 185-192. https://doi.org/10.20448/journal.509.2018.53.185.192

Department of Statistic. (2014). Labour Force Survey Report 2013.

Diemer, A., Nedelciu, E., Schellens, M., \& Gisladottir, J. (2018). Challenges for Sustainability in Critical Raw Material Assessments. International Journal of Management and Sustainability, 7(3), 156-179. https://doi.org/10.18488/journal.11.2018.73.156.179

Elzamly, A., \& Hussin, B. (2015). Classification and Identification of Risk Management Techniques for Mitigating Risks with Factor Analysis Technique in Software Risk Management. Review of Computer Engineering Research, 2(1), 22-38. https://doi.org/10.18488/journal.76/2015.2.1/76.1.22.38

Fareed, M., Isa, M. F. M., \& Noor, W. S. W. M. (2016). Human Resource Professionals' Effectiveness, Organizational Culture and High Performance Work System Link: Evidence from Pakistan. International Review of Management and Marketing, 6(7S), 335-344.

Fareed, M., Noor, W. S., Isa, M. F., \& Salleh, S. S. (2016). Developing Human Capital for Sustainable Competitive Advantage: The Roles of Organizational Culture and High Performance Work System. International Journal of Economic Perspectives, 10(4), 655-673.

Fatt, C. K., Khin, E. W., \& Heng, T. N. (2010). The impact of organizational justice on employee's job satisfaction: the Malaysian companies perspectives. American Journal of Economics and Business Administration, 2(1), 56-63. https://doi.org/10.3844/ajebasp.2010.56.63

Greenberg, J. (1987). A taxonomy of organizational justice theories. Academy of Management Review, 12(1), 9-22. https://doi.org/10.5465/amr.1987.4306437

Greenberg, J. (1990). Organizational justice: Yesterday, today, and tomorrow. Journal of Management, 16(2), 
399-432. https://doi.org/10.1177/014920639001600208

Greenberg, J. (2009). Everybody talks about organizational justice, but nobody does anything about it. Industrial and Organizational Psychology, 2(2), 181-195. https://doi.org/10.1111/j.1754-9434.2009.01131.X

Ha, T. P. T., \& Tran, M. D. (2018). Review of Impacts of Leadership Competence of Project Managers on Construction Project Success. International Journal of Emerging Trends in Social Sciences, 4(1), 15-25. https://doi.org/10.20448/2001.41.15.25

Hamid, T., Reihaneh, M., \& Siroos, Z. K. (2016). The Effect on Turnover Intention on Empowering Employees According to Mediate the Interoperability of PNU Fars Province Employees. The Social Sciences, 11(06), 882-889.

Harrison, D. A., Newman, D. A., \& Roth, P. L. (2006). How important are job attitudes? Meta-analytic comparisons of integrative behavioral outcomes and time sequences. Academy of Management Journal, 49(2), 305-325. https://doi.org/10.5465/amj.2006.20786077

Haseeb, M., Abidin, I. S. Z., Hye, Q. M. A., \& Hartani, N. H. (2018). The Impact of Renewable Energy on Economic Well-Being of Malaysia: Fresh Evidence from Auto Regressive Distributed Lag Bound Testing Approach. International Journal of Energy Economics and Policy, 9(1), 269-275.

Haseeb., H. Z., G. Hartani., N. H., Pahi., M. H., \& Nadeem., H. (2019). Environmental Analysis of the Effect of Population Growth Rate on Supply Chain Performance and Economic Growth of Indonesia. Ekoloji, 28(107).

Hussien, F. M., \& Jones, E. (2016). The requirements of disabled customers: a study of British customers in Egyptian hotels. Journal of Tourism Management Research, 3(2), 56-73. https://doi.org/10.18488/journal.31/2016.3.2/31.2.56.73

Iacobucci, D., Saldanha, N., \& Deng, X. (2007). A meditation on mediation: Evidence that structural equations models perform better than regressions. Journal of Consumer Psychology, 17(2), 139-153. https://doi.org/10.1016/S1057-7408(07)70020-7

Iftikhar, M., Shahid, M. U., Shahab, M. H., Mobeen, M., \& Qureshi, M. I. (2016). Exploring the Relationship among Organizational Citizenship Behavior, Psychological Empowerment and Turnover Intensions with the Mediating Role of Affective Commitment. International Review of Management and Marketing, 6(4S), $296-304$.

Ince, M., \& Gül, H. (2011). The Effect of Employees' Perceptions of Organizational Justice on Organizational Citizenship Behavior: An Application in Turkish Public Institutions. International journal of Business and Management, 6(6), 134-149. https://doi.org/10.5539/ijbm.v6n6p134

Islam, T., Ahmed, I., \& Ahmad Ungku, N. B. U. (2015). The influence of organizational learning culture and perceived organizational support on employees' affective commitment and turnover intention. Nankai Business Review International, 6(4), 417-431. https://doi.org/10.1108/NBRI-01-2015-0002

Kabir, K. H., \& Aftab, S. (2017). Exploring Management Strategies for Freshwater Wetland: Policy Options for Southwest Coastal Region in Bangladesh. Asian Development Policy Review, 5(2), 70-80. https://doi.org/10.18488/journal.107.2017.52.70.80

Karatepe, O. M., \& Shahriari, S. (2014). Job embeddedness as a moderator of the impact of organisational justice on turnover intentions: a study in Iran. International Journal of Tourism Research, 16(1), $22-32$. https://doi.org/10.1002/jtr.1894

Keni, R. M., Teoh Ai Ping, \& Rubiah Ab Rahman. (2013, November, 21-22). Turnover Intention Trend Among Commercial Banks in Penang, Malaysia. Paper presented at the International Conference on Entrepreneurship and Business Management (ICEBM 2013), Sanur, Bali.

Khan, S. K., \& Rashid, M. Z. A. (2012). The Mediating Effect of Organizational Commitment in the Organizational Culture, Leadership and Organizational Justice Relationship with Organizational Citizenship Behavior: A Study of Academicians in Private Higher Learning Institutions in Malaysia. International Journal of Business and Social Sciences, 3(8), 83-91.

Kim, W., \& Hyun, Y. S. (2017). The impact of personal resources on turnover intention: The mediating effects of work engagement. European Journal of Training and Development, 41(8), 705-721. https://doi.org/10.1108/EJTD-05-2017-0048

Koys, D. J. (2001). The effects of employee satisfaction, organizational citizenship behavior, and turnover on 
organizational effectiveness: A unit level, longitudinal study. Personnel Psychology, 54(1), 101-114. https://doi.org/10.1111/j.1744-6570.2001.tb00087.x

Krejcie, R. V., \& Morgan, D. W. (1970). Determining sample size for research activities. Educational and psychological Measurement, 30(3), 607-610. https://doi.org/10.1177/001316447003000308

Labrague, L. J., Gloe, D. S., McEnroe-Petitte, D. M., Tsaras, K., \& Colet, P. C. (2018). Factors influencing turnover intention among registered nurses in Samar Philippines. Applied Nursing Research, 39, 200-206. https://doi.org/10.1016/j.apnr.2017.11.027

Langove, N., Isha, A. S. N. B., \& Javaid, M. U. (2016). The Mediating Effect of Employee well-being in relation to Role Stressors and Turnover Intention: A Conceptual Study. International Review of Management and Marketing, 6(4S), 150-154.

Lau, P. Y. Y., McLean, G. N., Lien, B. Y.-H., \& Hsu, Y.-C. (2016). Self-rated and peer-rated organizational citizenship behavior, affective commitment, and intention to leave in a Malaysian context. Personnel Review, 45(3), 569-592. https://doi.org/10.1108/PR-04-2014-0083

Li, J. J., Kim, W. G., \& Zhao, X. R. (2017). Multilevel model of management support and casino employee turnover intention. Tourism Management, 59, 193-204. https://doi.org/10.1016/j.tourman.2016.08.006

Lin, C.-P., Tsai, Y.-H., \& Mahatma, F. (2017). Understanding turnover intention in cross-country business management. Personnel Review, 46(8), 1717-1737. https://doi.org/10.1108/PR-07-2016-0176

Long, C. S. A., Anisa Kowang, Tan Owee Fei, \& Goh Chin. (2016). An Analysis on the Relationship between Work Family Conflict and Turnover Intention: A Case Study in a Manufacturing Company in Malaysia. International Business Management, 10(3), 176-182.

Lv, A., Shen, X., Cao, Y., Su, Y., \& Chen, X. (2012). Conscientiousness and organizational citizenship behavior: The mediating role of organizational justice. Social Behavior and Personality: An International Journal, 40(8), 1293-1300. https://doi.org/10.2224/sbp.2012.40.8.1293

Martinez, T. M., \& Podsakoff, N. P. (2016). Traditional Predictors of OCB: Reviews and Recommendations for Future Research. Paper presented at the Annual Conference of the Academy of Management, Anaheim, California, USA. https://doi.org/10.5465/ambpp.2016.14716symposium

Mazlum Çelik, A. Ç. (2013). The Mediating Role of Work Overload on the Effects of Organizational Citizenship Behavior on Job Performance and Turnover Intention. Ege Academic Review, 13(1), 11-20.

Mohammad, J., Habib, F. Q. B., Adnan, M., \& Alias, B. (2010). Organizational Justice and Organizational Citizenship Behavior in Higher Education Institution. Global Business \& Management Research, 2(1), 13-32.

Muqadas, F., Rehman, C. A., \& Aslam, U. (2017). Organizational justice and employee's job dissatisfaction: a moderating role of psychological empowerment. Pakistan Business Review, 18(4), 848-864.

Nasyira, M., Othman, M., \& Ghazali, H. (2014). Predictors of intention to stay for employees of casual dining restaurant in Klang Valley area. International Food Research Journal, 21(3), 863-871.

Nazal, A. I. (2017). Financial Tables Reports Gaps in Jordanian Islamic Banks. The Economics and Finance Letters, 4(2), 9-15. https://doi.org/10.18488/journal.29.2017.42.9.15

Ngigi, L. N., \& Odiyo, W. (2017). The Influence of Strategy Implementation on the Performance of Micro Enterprises in Ruiru Sub County, Kiambu County, Kenya. International Journal of Management and Sustainability, 6(1), 1-7. https://doi.org/10.18488/journal.11.2017.61.1.7

Noruzy, A., Shatery, K., Rezazadeh, A., \& Hatami-Shirkouhi, L. (2011). Investigation the relationship between organizational justice, and organizational citizenship behavior: The mediating role of perceived organizational support. Indian Journal of science and Technology, 4(7), 842-847.

Obodo, N. A. (2018). Content Analysis of Time Management as a Tool for Corporate Effectiveness. International Journal of Applied Economics, Finance and Accounting, 2(2), 36-39. https://doi.org/10.33094/8.2017.2018.22.36.39

Ongori, H. (2007). A review of the literature on employee turnover. African Journal of Business Management, 1(3), 49-54.

Orora, W., Keraro, F. N., \& Wachanga, S. W. (2014). Using cooperative e-learning teaching strategy to enhance students' creativity in secondary school biology: A study of selected schools in Nakuru County, Kenya. 
International Journal of Education and Practice, 2(6), 137-146. https://doi.org/10.18488/journal.61/2014.2.6/61.6.137.146

Osborne, J. W. (2010). Improving your data transformations: Applying the Box-Cox transformation. Practical Assessment, Research \& Evaluation, 15(12), 1-9.

Paillé, P. (2013). Organizational citizenship behaviour and employee retention: how important are turnover cognitions?. The International Journal of Human Resource Management, 24(4), 768-790. https://doi.org/10.1080/09585192.2012.697477

Paillé, P., \& Grima, F. (2011). Citizenship and withdrawal in the workplace: relationship between organizational citizenship behavior, intention to leave current job and intention to leave the organization. The Journal of Social Psychology, 151(4), 478-493. https://doi.org/10.1080/00224545.2010.507266

Parasız, Ö., Koç, M., Ilgar, E., \& Şahin, M. Y. (2017). Relationship between organizational commitment and turnover intentions of academics. Journal of Human Sciences, 14(4), 4065-4076. https://doi.org/10.14687/jhs.v14i4.5076

Patiraj, K., \& Shivani, T. (2017). Studying the Impact of Organizational Citizenship Behavior on Organizational Effectiveness. International Academic Journal of Organizational Behavior and Human Resource Management, 4(1), 9-21.

Podsakoff, N. P., Whiting, S. W., Podsakoff, P. M., \& Blume, B. D. (2009). Individual-and organizational-level consequences of organizational citizenship behaviors: A meta-analysis. Journal of Applied Psychology, 94(1), 122-141. https://doi.org/10.1037/a0013079

Ponnu, C., \& Chuah, C. (2010). Organizational commitment, organizational justice and employee turnover in Malaysia. African Journal of Business Management, 4(13), 2676-2692.

Preacher, K. J., \& Hayes, A. F. (2004). SPSS and SAS procedures for estimating indirect effects in simple mediation models. Behavior Research Methods, Instruments, \& Computers, 36(4), 717-731. https://doi.org/10.3758/BF03206553

Purba, D. E., Oostrom, J. K., Van Der Molen, H. T., \& Born, M. P. (2015). Personality and organizational citizenship behavior in Indonesia: The mediating effect of affective commitment. Asian Business \& Management, 14(2), 147-170. https://doi.org/10.1057/abm.2014.20

Purnama, C. (2014). Improved Performance Through Empowerment of Small Industry. Journal of Social Economics Research, 1(4), 72-86.

Rekik, M. (2018). The Moderating Effect of Governance Mechanisms on the Relationship Between Innovation Strategy and the Performance. International Journal of Business, Economics and Management, 5(3), 68-93. https://doi.org/10.18488/journal.62.2018.53.68.93

Rurkkhum, S., \& Bartlett, K. R. (2017). Organizational citizenship behaviour for collectivist cultures: instrument development and human resource development implications. Human Resource Development International, 1-18. https://doi.org/10.1080/13678868.2017.1400820

Saoula, O., \& Johari, H. (2016). The Mediating Effect of Organizational Citizenship Behaviour on the Relationship between Perceived Organizational Support and Turnover Intention: A Proposed Framework. International Review of Management and Marketing, 6(7S), 345-354.

Saoula, O., Johari, H., \& Bhatti, M. A. (2016). The Mediating Effect of Organizational Citizenship Behavior on the Relationship Between Personality Traits (Big Five) and Turnover Intention: A Proposed Framework. International Business Management, 10(20), 4755-4766.

Saoula, O., Johari, H., \& Fareed, M. (2018). A conceptualization of the role of organisational learning culture and organisational citizenship behaviour in reducing turnover intention. Journal of Business and Retail Management Research (JBRMR), 12(4), 132-140. https://doi.org/10.24052/JBRMR/V12IS04/ART-13

Saraih, U. N., Aris, A. Z. Z., Sakdan, M., \& Ahmad, R. (2017). Factors Affecting Turnover Intention among Academician in the Malaysian. Higher Educational Institution Review of Integrative Business and Economics Research, 6(1), 1-15.

Sayed, A. A. A., Mohammad, R. D., Hossein, R., Yashar, S., \& Hamid, T. (2012). The Study on Relationship Between Organizational Justice, Organizational Citizenship Behavior, Job Satisfaction and Turnover Intentions 
a Comparison between Public Sector and Private Sector. International Business Management, 6(1), 22-31. https://doi.org/10.3923/ibm.2012.22.31

Sayin, F. K., Denton, M., Brookman, C., Davies, S., Chowhan, J., \& Zeytinoglu, I. U. (2019). The role of work intensification in intention to stay: A study of personal support workers in home and community care in Ontario, Canada. Economic and Industrial Democracy. https://doi.org/10.1177/0143831X18818325

Shackman, J. D. (2013). The use of partial least squares path modeling and generalized structured component analysis in international business research: A literature review. International Journal of Management, 30(3), 78.

Shahzad, S., \& Jamal, W. (2013). Impact of Organizational Justice and Employee Engagement on Organizational Citizenship Behavior: A Case of Private Sector Universities in Peshawar. Business \& Economic Review, 5(2), 55-64. https://doi.org/10.22547/BER/5.2.4

Su, R., Yang, Z., \& Dutta, A. (2018). Accounting Information Comparability and Debt Capital Cost Empirical Evidence from Chinese Listed Companies. Asian Economic and Financial Review, 8(1), 90-102. https://doi.org/10.18488/journal.aefr.2018.81.90.102

Sumaira Khalid, Ch. Abdul Rehman, \& Muqadas, F. (2018, January). Exploring the mediating role of affective commitment on organizational justice and turnover intention. Pakistan Business Review, 1012-1028.

Suryanto, T., Haseeb, M., \& Hartani, N. H. (2018). The Correlates of Developing Green Supply Chain Management Practices: Firms Level Analysis in Malaysia. International Journal of Supply Chain Management, 7(5), 316.

Tabachnick, B. G., \& Fidel, L. S. (2007). Using multivariate statistics (5th ed.). Boston: Pearson Education Inc.

Tett, R. P., \& Meyer, J. P. (1993). Job satisfaction, organizational commitment, turnover intention, and turnover: path analyses based on meta-analytic findings. Personnel Psychology, 46(2), 259-293. https://doi.org/10.1111/j.1744-6570.1993.tb00874.x

Thibaut, J. W., \& Walker, L. (1975). Procedural justice: A psychological analysis. L. Erlbaum Associates Hillsdale, NJ; New York, NY.

Ton, Z., \& Huckman, R. S. (2008). Managing the impact of employee turnover on performance: The role of process conformance. Organization Science, 19(1), 56-68. https://doi.org/10.1287/orsc.1070.0294

Walumbwa, F. O., Hartnell, C. A., \& Oke, A. (2010). Servant leadership, procedural justice climate, service climate, employee attitudes, and organizational citizenship behavior: a cross-level investigation. Journal of Applied Psychology, 95(3), 517-529. https://doi.org/10.1037/a0018867

Wang, Q., \& Bowling, N. A. (2016). A Comparison of General and Work-specific Personality Measures as Predictors of Organizational Citizenship Behavior. International Journal of Selection and Assessment, 24(2), 172-188. https://doi.org/10.1111/ijsa.12139

Williams, L. J., \& Anderson, S. E. (1991). Job satisfaction and organizational commitment as predictors of organizational citizenship behaviors and in-role behaviors. Journal of Management, 17(3), 601-617. https://doi.org/10.1177/014920639101700305

Yadav, P., \& Punia, B. (2013). Organisational Citizenship Behavior: A Review of Antecedent, Correlates, Outcomes and Future Research Directions. IJHPD, 2(2), 1-19. 